\title{
Attitudes and Challenges Towards Virtual Classes in Learning English Language Courses From Students' Perspectives at Taibah University During COVID-19 Pandemic
}

\author{
Mohammad Abd Alhafeez Ali Ta'amneh \\ Taibah University, Saudi Arabia
}

\begin{abstract}
Educational institutions all over the world have shifted from conventional education to distance (online) learning system as a result of the ongoing COVID-19 pandemic. Identifying the advantages and disadvantages of online learning during the present pandemic can help the professors, educators, and educational experts in taking and adopting new appropriate decisions that match the students' needs in such difficult conditions. This study aimed at investigating the first year students' attitudes towards virtual classes in learning English courses. It also aimed to identify the obstacles that encounter them while using this kind of learning. The sample of the study consisted of 336 students at Taibah University during the first semester of the academic year 2020/2021. A well-designed online questionnaire was used to collect data. Results revealed that students' attitudes towards the use of the online learning were positive. Students considered this kind of learning as the best strategy during COVID-19 pandemic. The results also showed that the students faced some pedagogical, technical and personnel obstacles while attending virtual classes.
\end{abstract}

Index Terms—attitudes, distance learning, learning management system, online learning, virtual education.

\section{INTRODUCTION}

It is a clear cut that the emergence of Information Technology (IT) has spread all over the world and it has been used in every aspect of life. Educationalists tend to take advantage of computerized utilities and all other means of IT to benefit the process of teaching and learning. Al-Zaidiyeen, Mei and Fook (2010) affirm that Information and Communication Technologies (ICTs) have proved to be active and effective tools for educational process and "it has extended and transformed the way students learn and teachers teach" (p. 211). Because of the increase awareness of the importance of ICTs to be implemented in education, educational institutions launch many electronic learning projects to introduce appropriate technologies and therefore the quality of teaching and learning can be successfully enhanced. The global crisis of COVID-19 pandemic has forced all educational institutions to change their instruction from face-to-face learning to distance (online) learning classes. Alahamdi and Alraddadi (2020) state that "The development of e-learning has expanded to a great extent to include a variety of online learning approaches such as virtual classes, video conferencing and blended learning" (p.57). The Kingdome of Saudi Arabia has been affected by COVID-19 pandemic. All educational institutions have been closed and changed their instruction to distance learning as the only choice to continue their learning during this pandemic. Accordingly, students have attended their lectures online through virtual classes.

The use of the internet helps learners and instructors in their learning and teaching (Sallbego \& Tumolo, 2015). Many empirical researches investigate the positive effects of integrating internet technology in EFL teaching and learning (AlTale, 2014). As a result of the effectiveness of the internet in educational setting, the Kingdom of Saudi Arabia uses it in different educational fields. The online learning includes the Blackboard Platform used at Taibah University which facilitates e-learning system for students and instructors. The virtual classroom is a type of educational tools presented in the Blackboard. Virtual classes according to Cakiroglu (2014) include a variety of learning and teaching services, such as chat, whiteboard, break-out rooms, application sharing, synchronized web browsing, and feedback. It also has many advantages that motivate both learners and teachers to develop the learning process, such as overcoming geographical barriers, recording the session, reducing students' anxiety and increasing their motivations, and improving communication and collaboration (Yadav, 2016). Many universities and educational institutions all over the world during COVID-19 pandemic move to online learning as the only available choice for learning. Using virtual classes in English language learning and teaching becomes widely used during the present pandemic. They allow both teachers and students to communicate, share, and exchange their ideas through online platforms (Yadav, 2016).

What matters the most in this research is the students' attitudes since they play important roles in the acceptance and use of virtual classes. Kim, Chun \& Song (2009) define attitude towards a behavior as "an individual's positive or negative evaluation of performing the behavior"(P.64). It involves a person's judgment about behavior whether it is good or bad and then a person can behave in a certain way toward something. From a psychological perspective, Affizal 
and Sahak (2009) define the word attitude "as a subjective or mental preparation for action. It defines outward and visible postures and human beliefs. Attitudes determine what each individual will see, hear, think and do" (p.59). In other words, such definition involves the characteristics or the qualities that motivate and stimulate a person to behave in a certain way to make him/her likes or dislikes a property. Therefore, attitudes direct someone's attention to go for something or even react against it occasionally. In relation to technology, attitude can be affected positively or negatively. Researches show that the ultimate success or failure of technology use in education depends heavily on the person's attitude towards technology use (Abirini 2006).

\section{StATEMENT OF THE PROBLEM}

The use of online learning platforms contributes to benefit students, teachers and administration if they accept to use and get advantage of it. Therefore, technology acceptance, as perceived by Davis (1989) determines the factors that affect the actual use of educational technology in school context. One of the main aims of online learning is to enhance the positive tendency and to increase the society awareness about Information and Communication Technology and its role on the process of teaching and learning. Using virtual classes in online learning is considered as important as physical attendance in face to face learning. Students have enough knowledge and experience to learn online and attend virtual classes efficiently and frequently. As a result of that, the researcher tends to carry out this investigation to recognize the students' attitudes towards the effect of the virtual classes and identify the encountered obstacles that hinder their actual use.

\section{SIGNIFICANCE OF THE STUDY}

This study drives its importance from the fact that it discovers and sheds the light on the students' attitudes towards the use of EFL virtual classes. In fact, the study is important because:

1. The increase awareness of the EFL virtual classes is directly reflected in the policies and visions of higher education in general and Taibah University in specific in Saudi Arabia. Taibah University offers significant importance to encourage administrative staff, instructors and student to implement online learning in every step they make.

2. The study aims to investigate the students' attitudes towards the use of online learning during COVID-19 pandemic. When the findings are identified, the positive or negative attitudes help educationalists account for the right modifications.

3. It is expected for the study to find the obstacles that students confront when they use attend virtual classes and then the study suggests some solutions.

4. The study may enrich the literature and library sources as it keeps up-to-date record.

\section{QUESTIONS OF THE STUDY}

The study attempts to answer the following questions:

1. What are the students' attitudes towards the use of EFL virtual classes in learning English courses?

3. What are the encountered obstacles that the students face while attending EFL virtual classes?

\section{LiMitATIONS OF THE STUDY}

1. The findings of the present study were limited to the students at Taibah University studied at Badr branch. Therefore, the findings cannot be generalized to other students in different areas.

2. The study may be repeated in other branches with a larger sample to investigate the students' attitudes.

3. Examining students' attitudes towards virtual classes after being enrolled in training session may affect the results and reduce the obstacles.

\section{DEFINITIONS OF TERMS}

1. Virtual class: It is a kind of electronic classroom used in the process of teaching and learning to make online learning more attractive and purposeful.

2. Attitude: It is a psychological tendency that is expressed by "evaluating a particular entity with some degree of favor or disfavor" (Eagly \& Chaiken, 1993, p. 1).

3- Electronic learning: It is the process of using electronic applications to facilitate students' learning and improve their understanding.

4-Students' attitudes: They are the students' general tendency to react favorably or unfavorably to an object (Morris and Maisto, 2005). In this study the students' attitudes are measured by their answers to the items of the questionnaire.

\section{THEORETICAL BACKGROUND}

The term electronic learning, such as internet, intranet, virtual classroom and computer-based learning, can be defined as the process by which we can use electronic application and software to improve and enrich learning. 
Nowadays, universities are fully provided with all means of technology to facilitate the teaching and learning processes. Bena and James (2001) mention some benefits for using technology in learning. They assert that technology increases students' ability and motivates them to do their tasks eagerly. It also prepares students for success in a technologycentered world of work. Furthermore, it helps students to manage and use information so they become more productive and responsible. Smith (2013) and Madison (2011) assert the importance of using technology in educational process through making education more enjoyable and attractive.

Using internet technology and educational platforms in learning and teaching, such as Blackboard platform, are used globally to enable users to manage the contents of learning activities and overall development of students and faculties as well. According to Beatty (2013), a virtual classroom is a kind of "electronic classroom that can be expandable in time, space, and content" ( p. 156). In virtual learning, instructors and students "are not present physically in the same class; instead, they remain separate different locations and connect via different IT (Information Technology) applications" (Shahzad, Hussain, Sadaf, Sarwat, Ghani\& Saleem, 2020, p.4). As a result of COVID-19 pandemic, many counties suggest educational institutions to use virtual learning programs and different educational applications so the instructors can deliver their lectures to their students through online platforms.

According to Yadav (2016), virtual learning motivates learners and instructors to communicate and share ideas through oral communication, texts, video and audio conversations, chat and Power Point presentations. MunozOrganero, Munoz-Merino \& Kloos (2010) suggest that exploring motivational problems for some students early give teachers a chance to present additional encouraging activities for them in the future. That is to say, if problems behind students' abstain from using the virtual classes are identified, teachers can design new tasks and assignment that match the students' need and interest. Additionally, Alahmadi \& Alraddadi (2020) assert that creating environment that encourages students to communicate in English is considered as a challenge in teaching English as a Foreign Language (EFL). Indeed, many researchers view EFL virtual classes as a potential solution to this challenge because of the benefits of these classes for English students. (Alahmadi\& Alraddadi, 2020; Bianchi, Yyelland, Yang \& McHarg, 2019; Hussein, 2016; McBrien, Cheng, \& Jones., 2009). Consequently, students become more motivated to get advantage of all utilities of virtual classes and their level of confidence starts to increase more. Some researchers consider online learning as helpful and efficient educational tools of electronic learning systems for both instructors and learners. (Ta'amneh, 2014; Liaw, 2008; Chang, 2013). "To know the benefits of technology in educational processes, both learners and instructors have to use it efficiently and successfully in their practices" (Ta'amneh, 2020. p.83).

\section{LITERATURE REVIEW}

The effectiveness of online and distance learning has been investigated by many researchers. Alahamdi and Alraddadi (2020) discovered that the students had positive attitudes towards using virtual classes for foreign language learning. Furthermore, Al-Qahtani (2019) found that the students and teachers had positive attitudes towards teaching and learning via EFL virtual classes. His findings also agreed with the important role of virtual classes in developing communication skills. In the same vein, Cakiroglu (2014) asserted that using the internet and it's applications in the educational process helped the development of communication among students, instructors, and sharing resources for knowledge. His results also emphasized that "Virtual classrooms are one of the main components of synchronous settings that share certain similarities with real classrooms"( p. 1). Sarica and Cavus (2008) considered online learning as an alternative way to study English and give students good opportunities for the development of learning processes and improving their language skills. Similarly, Sanders (2012) conducted a study to examine the effect of e-learning tools in improving students' English communication and performance. The results showed that using these tools outside the classroom encouraged students' engagement in the process of learning. Likewise, Hariri and Bahanshal (2015) found a positive relationship between students' proficiency in English language as a result of employing e-learning system. Similarly, in a study that compared students' use of two different platforms, Al-Mubireek (2019) found positive attitudes towards learning via online learning. Likewise, Anas (2020) confirmed that Saudi students at Bisha University appreciated the interactivity of online learning tools, such as discussion forums and collaborative activities. According to Ta'amneh (2017), using online technological educational systems in the process of learning gave both students and teachers more educational advantages and assisted them to overcome the problems of conventional learning through discussing, explaining and exchanging ideas connected to their courses at any time and everywhere.

Studies done on the attitudes towards electronic learning in general and virtual classes in particular were so many in numbers in the literature especially those studies that were conducted on teachers' and students' attitude towards technology in learning. However, studies done on students' attitudes towards EFL virtual classes were limited in number. Therefore, the researcher concentrated on the studies conducted on the EFL virtual classes and students' attitudes towards the use of them during COVID-19 pandemic in the related literature. Here are some of them:

Alhawiti (2017) examined the effectiveness of virtual classes on student English proficiency at Tabuk Community College during the first term of the academic year 2016-2017. The sample of the study consisted of 224 students. The participants were divided into two groups (control and experimental). The independent variable consisted of the proposed virtual classes used to teach the students of the experimental group at Tabuk Community College. The dependent variable was student English proficiency. The results showed that the students in the experimental group 
were better and higher on the English achievement test than other students in the control group as a result of attending EFL virtual classes.

Al-Qahtani (2019) investigated teachers' and students' attitudes' towards EFL virtual classes and the effects of these classes on improving communication skills. The sample consisted of thirty teachers and students at King Khalid University in Abha. They were divided into two groups (control and experimental). The results showed that the majority of the participants had positive attitudes towards EFL virtual classes. They agreed that these classes play a vital role in developing communication skills.

Alahmadi and Alraddadi (2020) investigated the impact of the virtual classroom on English language interaction. Ninety students in an English language course in the Preparatory Year Program at a Saudi English Language Centre participated in this study. They were asked to respond to the questionnaire developed by the researchers to measure their attitudes towards this kind of learning. The results revealed that there was a satisfied interaction among students in virtual classes. Besides, they indicated that the students had positive attitudes towards using these classes for learning English language skills.

Adnan and Anwar (2020) examined the attitudes of Pakistani students towards compulsory digital and distance learning university courses during COVID-19 pandemic. The sample of their study consisted of 84 female and 42 male higher education students who were surveyed to find their attitudes towards online education in Pakistan. The findings of the study indicated that online learning could not produce good results in Pakistan because of the internet problems and other technical and monetary issues in addition to other difficulties like the lack of face-to-face communication with their teachers and the absence of conventional classroom socialization. The results also showed that online learning was not as effective as traditional learning although it played a vital role during the pandemic. The result also indicated that curriculum designers and teachers need to develop and improve their curriculum and design suitable content for online meetings.

Hamouda (2020) conducted a study to discover the effects of using the virtual classes on English speaking skills and to study their attitudes towards the use of virtual classes at Qassim University. The study consisted of seventy students distributed into two groups (control and experimental) during the first semester of the academic year 2019-2020. The results indicated that the students in the experimental group scored better on the speaking test than those in the control group. The findings also revealed that students had positive attitudes towards using virtual classes.

Khalilia (2020) did a study to determine students' attitudes and difficulties towards online learning during the times of crisis and to help teachers, students and the educational institution in taking appropriate decisions in such difficult situations. Two hundred and eighty students at Al-Istiqlal University responded to online questionnaire during the second semester of the academic year 2019-2020. The results indicated that the participants had appositive attitudes towards online learning. It also revealed that the participants encountered some obstacles while using the e-learning process related to computer skills, gender, and internet connection.

Lassoued, Alhendawi and Bashitialshaaer (2020) conducted a study to reveal the obstacles of online learning during COVID-19 pandemic. The participants consisted of 400 professors and students from Algeria, Egypt, Palestine, and Iraq. The researchers wanted to investigate the different ways used by students to continue learning outside universities as a result of COVID-19 pandemic. They used a questionnaire to achieve the objectives of their study. The results indicated that the participants encountered self-imposed difficulties, as well as pedagogical, technical, and financial or organizational obstacles.

It has been noticed that the use of technology in education enhances the teaching and learning process. Using virtual classes facilitate such a process and help teachers prepare the material and make it accessible anytime. Students also can get access to this material, do the task, modify it and then share it with other students, too. Students tend to react positively towards the use of technology in education and the majority of the students perceive the virtual class as a helping system for their learning. Administrators and teachers recommend using this kind of learning since it saves time, costs less, and creates a social and helpful network between teachers, students and their parents as well.

The present study investigates the recent use of EFL virtual classes at Taibah University and investigates both the students' attitudes towards the use of these classes in learning online English courses and students' encountered obstacles that hinder them while using this technology. In fact, this study sheds the light on the students' actual use of EFL virtual classes among university students at Taibah University and offers some solutions to help learners get more benefits and then perform better while learning.

\section{METHODS AND PROCEDURES}

\section{Population and Sample of the Study}

The population of the study consisted of all students at Taibah University $\backslash$ Badr branch during the academic year 2020-2021. The sample of the study consisted of 336 students. Twenty students were chosen randomly to validate the instruments. The respondents to the main questionnaires were 336 students who completed filling in the questionnaires.

\section{Instruments of the Study}

The study consisted of two questionnaires. They were developed originally by the researcher. The first questionnaire was consisted of 20 items used to find the students' attitudes towards EFL virtual classes during COVID-19 pandemic. The second questionnaire examined the encountered obstacles from students' perspectives. 


\section{Validity of the Instruments}

The first draft of the questionnaires was given to a jury of seven experts in the field of English language teaching. They held a meeting and suggest some recommendations. Their recommendations were analyzed and taken into consideration.

\section{Reliability of the Instruments}

To establish the reliability of the questionnaires, the researcher conducted a pilot study on 20 students who were not included in the sample of this study. The questionnaires were distributed to those students to answer their items and then the copies were collected. After two weeks, the questionnaires were submitted in the same way. To calculate the responses, it was found 0.830 by the use of Person Correlation. In fact, it is considered a reasonable value to conduct this study.

\section{Data Collection Procedures}

This study was conducted during the first semester of the academic year 2020/2021. After validating and establishing the reliability of the questionnaires, the researcher distributed the copies of the questionnaires to students. The researcher explained the purpose of the study to them thoroughly and assured them that their responses would be kept confidential and would be used only for academic purposes.

\section{Results}

This section presents the findings of the students' attitudes towards EFL virtual classes in learning English language courses and their encountered obstacles while practicing this kind of learning. To answer the first question (What are the students' attitudes towards virtual classes in learning English language courses), the participants were asked to respond to 20 Likert-scale items measuring the students' attitudes towards EFL virtual classes in learning English language courses. The results of descriptive analysis (percentages, means, and standard deviations) of the participants' responses on each item of the questionnaire were calculated. Table 1 presents the results. 
TABLE 1

Percentages, Means And Standard Deviations Of The Students' Attitudes Towards Virtual Classes In Learning English LANGUAGE COURSES

\begin{tabular}{|c|c|c|c|c|c|c|c|c|}
\hline \multirow[t]{2}{*}{ No } & \multirow[t]{2}{*}{ Item } & \multicolumn{5}{|c|}{ Percent \% } & \multirow[t]{2}{*}{ Mean } & \multirow[t]{2}{*}{ St. D } \\
\hline & & S. $\mathbf{A g}$ & Ag. & Un & Dis & S. Dis & & \\
\hline 1 & Virtual classes help me get access to the information faster. & 35.1 & 40.8 & 12.5 & 6.3 & 5.4 & 3.94 & 1.099 \\
\hline 2 & $\begin{array}{c}\text { Virtual learning motivates me to look at details about target } \\
\text { topics. }\end{array}$ & 27.7 & 46.7 & 14.6 & 6.5 & 4.5 & 3.87 & 1.035 \\
\hline 3 & $\begin{array}{l}\text { Virtual classes change my learning techniques and } \\
\text { strategies to be more autonomous. }\end{array}$ & 29.5 & 43.2 & 17.0 & 7.4 & 3.0 & 3.89 & 1.010 \\
\hline 4 & $\begin{array}{c}\text { Virtual education provides learners with relevant, valuable, } \\
\text { and comprehensive resources. }\end{array}$ & 30.7 & 40.5 & 16.4 & 8.3 & 4.2 & 3.85 & 1.077 \\
\hline 5 & $\begin{array}{c}\text { Virtual classes make the process of English learning more } \\
\text { attractive and competitive. }\end{array}$ & 35.4 & 38.4 & 8.9 & 9.8 & 7.4 & 3.85 & 1.219 \\
\hline 6 & $\begin{array}{c}\text { Virtual education enriches the curriculum and helps me } \\
\text { understand it better. }\end{array}$ & 31.5 & 37.8 & 13.7 & 10.7 & 6.3 & 3.78 & 1.182 \\
\hline 7 & $\begin{array}{c}\text { Online learning platforms makes the process of learning } \\
\text { English easier. }\end{array}$ & 36.6 & 29.8 & 16.4 & 11.3 & 6.5 & 3.80 & 1.217 \\
\hline 8 & $\begin{array}{c}\text { Online examinations and tasks develop my skills in dealing } \\
\text { with international exams. }\end{array}$ & 42.3 & 32.1 & 14.6 & 5.4 & 5.7 & 4.00 & 1.138 \\
\hline 9 & $\begin{array}{c}\text { I am more likely to improve my learning autonomy when } \\
\text { learning English through online platforms. }\end{array}$ & 36.6 & 35.7 & 18.5 & 5.7 & 3.6 & 3.96 & 1.049 \\
\hline 10 & $\begin{array}{c}\text { The process of communication is appropriate to get access } \\
\text { to the online learning platforms. }\end{array}$ & 32.1 & 40.5 & 11.9 & 8.9 & 6.5 & 3.83 & 1.167 \\
\hline 11 & $\begin{array}{l}\text { Virtual learning is better than conventional learning in } \\
\text { improving my academic achievement. }\end{array}$ & 29.5 & 32.4 & 15.2 & 11.3 & 11.6 & 3.57 & 1.328 \\
\hline 12 & $\begin{array}{l}\text { The online meetings and virtual lectures motivate me to } \\
\text { participate in English without fearing. }\end{array}$ & 42.0 & 31.0 & 16.4 & 7.7 & 3.0 & 4.01 & 1.079 \\
\hline 13 & $\begin{array}{l}\text { Online learning devices are very useful for learning } \\
\text { English language skills. }\end{array}$ & 37.8 & 34.8 & 17.9 & 7.1 & 2.4 & 3.99 & 1.029 \\
\hline 14 & $\begin{array}{l}\text { I like to communicate in English with students more } \\
\text { through online learning platforms. }\end{array}$ & 29.5 & 37.2 & 17.9 & 11.3 & 4.2 & 3.76 & 1.118 \\
\hline 15 & $\begin{array}{c}\text { Virtual learning provides me with different learning } \\
\text { sources }\end{array}$ & 32.4 & 47.6 & 11.6 & 5.4 & 3.0 & 4.01 & 0.962 \\
\hline 16 & $\begin{array}{l}\text { Virtual classes change the ways of communication between } \\
\text { students and instructors. }\end{array}$ & 33.9 & 46.1 & 12.8 & 3.6 & 3.6 & 4.03 & 0.966 \\
\hline 17 & $\begin{array}{l}\text { I understand the instructions easily to attend virtual } \\
\text { lectures. }\end{array}$ & 39.0 & 42.3 & 7.7 & 8.3 & 2.7 & 4.07 & 1.020 \\
\hline 18 & $\begin{array}{l}\text { I understand the instructions through virtual classes to } \\
\text { respond to the online exams and tasks easily. }\end{array}$ & 39.9 & 39.9 & 11.3 & 6.8 & 2.1 & 4.09 & 0.984 \\
\hline 19 & $\begin{array}{l}\text { Online learning in general and virtual classes in specific } \\
\text { help me to communicate with learners all over the world. }\end{array}$ & 44.0 & 38.1 & 10.4 & 4.8 & 2.7 & 4.16 & 0.976 \\
\hline 20 & $\begin{array}{c}\text { Virtual learning provides me with different learning } \\
\text { sources }\end{array}$ & 35.1 & 44.6 & 14.0 & 3.0 & 3.3 & 4.05 & 0.951 \\
\hline
\end{tabular}

After examining table 1, it is obvious that the mean score ranges from (3.57 to 4.16). In fact, the results show that the items of the highest statistical analysis of mean scores were: item 19 (Online learning in general and virtual classes in specific help me to communicate with learners all over the world) with a mean score of (4.16) and with the highest percentage of S. Ag of (44.0\%), item 18 (I understand the instructions through virtual classes to respond to the online exams and tasks easily) with a mean score of (4.09), item 17 (I understand the instructions easily to attend virtual lectures) with a mean score of (4.07), item 20 (Virtual learning provides me with different learning sources) with a mean score of (4.05), and item 16 (Virtual classes change the ways of communication between students and instructors) with a mean score of (4.03). By contrast, the items of the lowest mean scores were: item 11 (Virtual learning is better than conventional learning in improving my academic achievement) with a mean score of (3.57) and item 14 (I like to communicate in English with students more through online learning platforms) with a mean score of (3.76). The students have positive attitudes towards online learning in general and EFL virtual classes in specific since the overall mean score for the all items is (3.93).

To answer the second question (What are the encountered obstacles that the students face while attending EFL virtual classes?), the participants were asked to respond to the questionnaire items that reflect the encountered obstacles. The answers were totally from students' own perspectives. 
TABLE 2

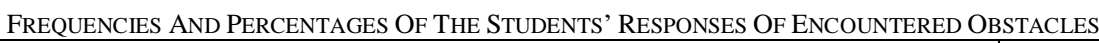

\begin{tabular}{|c|c|c|c|}
\hline No & Item & Frequency & Percentage $\%$ \\
\hline 1 & I do not have enough experience to deal with virtual classes. & 57 & 15.7 \\
\hline 2 & I do not have enough experience in the use of technology while attending virtual classes. & 39 & 11.1 \\
\hline 3 & I do not have suitable technological tools to attend the virtual lectures. & 59 & 16.8 \\
\hline 4 & The home environment is not appropriate for me to learn and communicate in virtual classes. & 70 & 19.6 \\
\hline 5 & I feel tired and bored in completing the online tasks in the given time. & 140 & 42.0 \\
\hline 6 & Attending a virtual class is difficult and makes me feel scared sometimes. & 84 & 25.2 \\
\hline 7 & There is no social connection between the teacher and students while and after virtual classes. & 105 & 31.7 \\
\hline 8 & There are no extra marks or moral incentives while attending virtual classes. & 184 & 55.1 \\
\hline 9 & I have problems with internet connection. & 164 & 49.5 \\
\hline 10 & I think that virtual classes do not account for the individual differences and do not satisfy all students' needs. & 195 & 58.6 \\
\hline
\end{tabular}

Table 2 reports the results of descriptive statistics of students' obstacles. Through a close look at the above Table, the researcher identified that the most frequent obstacles that the students faced while attending virtual classes were item 10 (I think that virtual classes do not account for the individual differences and do not satisfy all students' needs) with a percentage of $(58.6 \%)$, item 8 (There are no extra marks or moral incentives while attending virtual classes) with a percentage of $(55.1 \%)$, item 9 (I have problems with internet connection) with a percentage of (49.5\%), item 5 with a percentage of (42.0), and item 7 (There is no social connection between the teacher and students while and after virtual classes) with a percentage of (31.7). On the contrary, the least frequent items that indicate students' problems were items 2 (I do not have enough experience in the use of technology while attending virtual classes), item 1 (I do not have enough experience to deal with virtual classes), item 3 (I do not have suitable technological tools to attend the virtual lectures), item 4 (The home environment is not appropriate for me to learn and communicate in virtual classes), and item 6 (Attending a virtual class is difficult and makes me feel scared sometimes) with percentages of (11.1), (15.7), (83.2), (16.8) (19.6), and (25.2) respectively.

\section{DISCUSSION}

The purpose of the study was to investigate the students' attitude towards virtual classes in learning English language courses and their encountered obstacles while practicing this kind of learning. Concerning the results of the first question, the statistical analysis results showed that the overall mean score to the students' attitude was (3.93). In fact, this means that the students' attitudes towards this kind of learning reach the standard. As shown in table 1 , students prefer attending virtual (online) classes in learning English language courses during COVID-19 pandemic. An explanation to this comes from that fact that students view attending EFL virtual classes in the time of crises as an essential and necessary strategy to learn English language courses during COVID-19 pandemic. For example, item 19 which has one of the highest mean score (4.16) states that students strongly agree that virtual classes improve their academic achievement and communication skills. Students also agree that they view EFL virtual classes as a comfortable place to think critically and use higher level of thinking. They think beyond the text and solve problems by using different levels of thinking.

They also consider using online learning in general and virtual lectures in specific as enjoyable and interesting technique especially while doing course revision. They believe that using this kind of learning is effective in establishing a good relationship between teachers and students. Smith (2013) asserts this by saying that the integrating technology in the process of learning improves educational settings and makes it more enjoyable. Furthermore, Students agree with a percentage of $(69.3 \%)$ that the use of virtual classes can enrich the curriculum and help them understand it better. In fact, they think that these classes help them get different resources (i.e. visual, auditory and kinesthetic) as shown in item 6. In a way to explain these results, item 3,8, and 12 demonstrate that the majority of the students think that the use of the EFL virtual classes is an effective way to make them feel self-confident.

In addition, students consider virtual learning as a tool that helps them in organizing their homework, assignments, and time. They agree that the use of virtual learning saves their times and efforts. It seems that students download and send data electronically and by doing so the virtual class saves their time. The reasons behind these attitudes can be explained as the teachers may ask students to surf the internet looking for new information that help them understand or add more to curriculum. Educationally speaking, assignments and homework are used to assist the understanding and enrich the curriculum. Teachers assign the homework and check them back at specific time that both students and teachers know it. As a result, students feel it is a requirement to do their assignments and homework before the deadline. Sanders (2012), Hariri and Bahanshal (2015), Alhawiti (2017), Al-Qahtani (2019), Alahmadi and Alraddadi (2020), Hamouda (2020) and Khalilia (2020) asserted what this research ends up.

To identify the challenges that the students face while using the EFL virtual classes, the present study listed many obstacles that hinder students' use of these classes as can be seen in the answer to the second question of the study. 
Each obstacle will be fairly discussed from the most frequent one to the least one. Individual differences were not recognized by teachers as seen in the next most frequent item number 10 . Thus, $(58.6 \%)$ of the students were not stimulated to do tasks that reflect their needs and interests. Besides, almost half of the students (55.1) thought that there were no extra marks or moral incentives while attending EFL virtual classes. This problem could affect their interests negatively to attend these online classes. Brinol and Petty (2005:579) affirmed that "individual differences can determine what information is used to validate thoughts or attitudes." So that, when the tasks of the EFL virtual classes are interrelated with students' needs, this will increase their awareness and their desire to use these classes will be fostered.

Technical problems prevented some students from using EFL virtual classes effectively. Almost half of the participants with a percentage of (49.5\%) faced internet problems and had a difficulty in dealing with their EFL virtual classes. The same result was seen in the study of Lassoued, Alhendawi and Bashitialshaaer (2020) who stated that "one of the obstacles to achieving quality in distance learning during the COVID-19 pandemic was the weak internet speed in many remote areas, and the consequent interruptions in broadcasting and the impediment to following lessons" (p. 9). Students also demonstrated that they did not have enough time to use the EFL virtual classes. This is due to the fact that students are overwhelmed with university tasks, courses and exams. Additionally, almost one third of the students $(31.7 \%)$ thought that there were no social connections between teachers and students while and after the use of the EFL virtual classes as seen in item 7 . In fact, this is a challenge that explains the above item also.

The fifth item of the most frequent problem was that "I feel tired and bored in completing the online tasks in the given time" (item 5). Students expressed with a percentage of (42.0\%) that they felt tired with the online tasks in the given time used in the system. To explain this problem, the researcher thinks that students were not fully educated about the system in general and the process of attending online exams and assignments in specific. They might feel their practices are watched out. This made them feel bored and sometimes tired as a result of technophobia.

The least frequent obstacles were item 2 (I do not have enough experience in the use of technology while attending virtual classes), item 1(I do not have enough experience to deal with virtual classes), item 3 (I do not have suitable technological tools to attend the virtual lectures), item 4 (The home environment is not appropriate for me to learn and communicate in virtual classes), and item 6 (Attending a virtual class is difficult and makes me feel scared sometimes).It seems that most of the students do not face these obstacles while attending virtual classes.

\section{CONCLUSION}

The study aims to find out the students' attitudes towards the EFL virtual classes and to identify the obstacles that faced students while attending these classes. After doing analytic descriptive methods by terms of statistics to achieve this purpose, it has been found that students' attitudes towards the use of the EFL virtual classes tend to positive and reach the standard limits. Students prefer attending the EFL virtual classes during COVID-19 pandemic. They also strongly agree that the virtual classes help them in their academic achievement. The result shows also that students face many challenges as they get access to the EFL virtual classes. Obstacles were divided in two categories: the most frequent and the least frequent ones. The researcher recommends curriculum designers and decision makers to overcome any obstacles to make students feel more motivated to use the online learning and EFL virtual classes during crises.

\section{IMPLICATIONS OF THE STUDY}

Based on the findings of the study, the researcher recommends the following points:

1. Motivate students to be educated more about the utilities of the EFL virtual classes and keep them updated with new changes by means of training sessions.

2. It is advisable for the teachers to explore the individual differences of the students, stimulate and motivate them to use the EFL virtual classes by means of extra marks and other incentive tools.

3. Homework and assignments can be assigned electronically so that students surf the internet (educational platforms), download and upload their data.

4. Integration of other university subjects can be an effective tool. ICT teachers can inform and integrate other university subjects with theirs by means of electronic projects and materials.

5. Forums and video conferences have to be activated so that students exchange ideas and hold open discussion.

\section{REFERENCES}

[1] Adnan, M. \& Anwar, K. (2020). Online Learning amid the COVID-19 Pandemic: Students' Perspectives. Journal of Pedagogical Sociology and Psychology, 2(1), 45-51.

[2] Affizal, A. and Sahak, R. (2009). Teacher- Student Attachment and Teachers' Attitudes towards Work. Jurnal Pendidik, Jil, 24, 55-72.

[3] AL- Tale, M. (2014). The Effect of a Blended E-Learning Environment on EFL Students' Academic Performance, and Attitudes towards Internet-Assisted Language Learning and Teaching. King Khalid University Journal for Humanities, 23(1), 71-96. 
[4] Alahmadi, N. S. \& Alraddadi, B.M. (2020). The Impact of Virtual Classes on Second Language Interaction in the Saudi EFL Context: A Case Study of Saudi Undergraduate Students. Arab World English Journal, 11 (3) 56-72.

[5] Albirini, A. (2006). Teachers' Attitudes toward Information and Communication Technologies: The case of Syrian EFL Teachers. Computers \& Education, 47(4), 373-398.

[6] Alhawiti, M. M. F. (2017). The Effect of Virtual Classes on the Students English Achievement in Tabuk Community College. International Journal of Learning, Teaching and Educational Research, 16(5), 90-101.

[7] Al-Mubireek, A. (2019). E-learning in the English classroom: Comparing two e-learning platforms impacting preparatory year students' language learning. CALL-EJ, 20(2), 19-37.

[8] Al-Qahani, M. H. (2019). Teachers' and Students' Perceptions of Virtual Classes and the Effectiveness of Virtual Classes in Enhancing Communication Skills. Arab World English Journal (AWEJ), Special Issue: The Dynamics of EFL in Saudi Arabia, $223-240$.

[9] Al-Zaidiyeen, N., Mei, L., \& Fook, F. (2010). Teachers' Attitudes and Levels of Technology Use in Classrooms: The Case of Jordan Schools. International Education Studies, 3(2), 211-218.

[10] Anas, A. (2020). Perceptions of Saudi Students to Blended Learning Environments at the University of Bisha, Saudi Arabia. Arab. World English Journal (AWEJ) Special Issue on CALL (6). 261-277.

[11] Beatty, K. (2013). Teaching \& researching: Computer-assisted language learning. London: Routledge.

[12] Bena, K. \& James, M. (2001). Information Technology for Schools, Creating Practical Knowledge to Improve Students' Performance. Jossey-Bass A Wiley Company San Francisco

[13] Bianchi, R., Yyelland, B., Yang, J., \& McHarg, M. (2019). Avatar kinect: Drama in the virtual classroom among L2 learners of English. The Qualitative Report, 24(13), 58-74.

[14] Brinol, P., \& Petty, R. E. (2005). Individual Differences in Attitude Change. In D. Albarracín, B. T. Johnson, \& M. P. Zanna (Eds.), The Handbook of Attitudes and Attitude Change (pp. 575-616). Hillsdale, NJ: Erlbaum.

[15] Cakyroglu, U. (2014). Evaluating Students' Perspectives about Virtual Classrooms with Regard to Seven Principles of Good Practice. South African Journal of Education, 34(2), 1-19.

[16] Chang, C. (2013). Exploring the Determinants of E-Learning Systems Continuance Intention in Academic Libraries. Library Management, 34(1), 40-55.

[17] Davis, F. D. (1989). Perceived Usefulness, Perceived Ease of Use, and User Acceptance of Information Technology. MIS Quarterly, 13 (3), 319-340.

[18] Eagly, A. H., \& Chaiken, S. (1993). The psychology of attitudes. Fort Worth, TX: Harcourt Brace Jovanovich College Publishers.

[19] Hamouda, A. (2020). The effect of virtual classes on Saudi EFL students' speaking skills. International Journal of Linguistics, Literature and Translation, 3(4), 174-204.

[20] Hariri, R. O., \& Bahanshal, D. A. (2015). Maximizing L2 interaction through using Edmodo in Saudi EFL classrooms. International Journal of Linguistics, Literature and Culture, 2 (4), 48-60.

[21] Hussein, E.T. (2016). The effectiveness of using blackboard in improving the English listening and speaking skills of the female students at the University of Hail. Advances in Social Sciences Research Journal, 3(12), 81-93.

[22] Khalilia, W. (2020). Attitudes and Challenges towards E-Learning System in Time of Covid-19 from the Perspective of AlIstiqlal University Students. Elixir Edu. Tech, 145, 54676-54682.

[23] Kim, Y.J., Chun, J.U., and Song, J. (2009). Investigating the Role of Attitude in Technology Acceptance from an Attitude Strength Perspective. International Journal of Information Management, 29 (1), 67-77.

[24] Lassoued, Z., Alhendawi, M. \& Bashitialshaaer, R. (2020). An Exploratory Study of the Obstacles for Achieving Quality in Distance Learning during the COVID-19 Pandemic. Education Science, 10(9), 232.

[25] Liaw, S. (2008). Investigating Students' Perceived Satisfaction, Behavioral Intention, and Effectiveness of E-Learning: A Case Study of the Blackboard System. Computers \& Education, 51(2), 864-873.

[26] Madison, ED. (2012). Face to Face: Virtual Teachers Can't Replace the Real Thing. [Online] Available: http://www.huffingtonpost.com/ed-madison/virtual-teachers-vs-real-teachers_b_813438.html (November 9, 2020).

[27] McBrien, J. L., Cheng, R., \& Jones, P. (2009). Virtual spaces: Employing a synchronous online classroom to facilitate student engagement in online learning. The International Review of Research in Open and Distributed Learning, 10(3). 1-17.

[28] Morris, C. G. and Maisto, A. A. (2005). Psychology: An Introduction, 12th Ed. New Jersey: Pearson, Prentice Hall.

[29] Munoz-Organero, M., Munoz-Merino, P. J., \& Kloos, C. D. (2010). Student Behavior and Interaction Patterns with an LMS as Motivation Predictors in E-Learning Settings. IEEE Transactions on Education, 53(3), 463-470.

[30] Salbego, N. \& Tumolo, C. (2015). Skype Classes: Teachers and Students' Perceptions on Synchronous Online Classes in Relation to Face-To-Face Teaching and Learning. International Journal of Language and Applied Linguistics, 1(3), 36-45.

[31] Sanders, K., S. (2012). An examination of the academic networking site Edmodo on student engagement and responsible learning, (5), (Unpublished Doctoral dissertation). University of South Carolina, Ann Arbor.

[32] Sarica, G. \& Cavus, N. (2008). Web-Based English Language Learning. Procedia-Social and Behavioral Sciences, 1 (1), $439-$ 445.

[33] Shahzad,S., Hussain,J., Sadaf,N., Sarwat,S., Ghani,U., \& Saleem, R. (2020). Impact of Virtual Teaching on ESL Learners' Attitudes under Covid-19 Circumstances at Post Graduate Level in Pakistan. English Language Teaching. 13(9).1-9.

[34] Smith, P. (2013) Benefits of Technology in Education. [Online]Available:http://edtechreview.in/news/705-benefits-oftechnology-in-education (22 -10-2013).

[35] Ta'amneh, M. (2014). The Effect of Using Educational Websites on First Year Students' Achievement in English Grammar in Badr Community college. Journal of Emerging Trends in Educational Research and Policy Studies (JETERAPS), 5(2), 184189.

[36] Ta'amneh, M. (2017). The Effect of Using WhatsApp Messenger in Learning English Language among University Students. International Research in Education (IRE), 5,(1), 143-151. 
[37] Ta'amneh, M. (2020).The Effect of Blackboard Learning on the Development of English Writing Skills among University Students. Journal of Education and Practice. 11(19), 83-91.

[38] Trayek, Fuad and Hassan, Sharifah. (2013). "Attitude towards the Use of Learning Management System among University Students: A Case Study". Turkish Online Journal of Distance Education-TOJDE 14 (3), 91-103.

[39] Yadav, G. (2016). Reflection on virtual classes: Spirit of the time. International Journal of Advanced Research, 4(4), 11621167.

Mohammad Abd Alhafeez Ali Ta'amneh is an Associate Professor of Teaching English as a Foreign Language (TEFL) at Taibah University. He got his BA in English language and Literature from Yarmouk University in 2002 and MA in Teaching English as a Foreign Language (TEFL) from Hashemite University in 2005. He received his Ph.D. in English Language Curriculum and Instruction from Yarmouk University in the Department of Curriculum and Instruction in 2012. His research interests include applied linguistics, blended learning, language teaching, e-learning, language in use, and language analysis. 